\title{
The Contemporary Global State System
}

The competitive state system of Europe propelled European nations to achieve two major feats in world history: one was the industrial revolution, and the other was the creation of a western-centered global state system. The industrial revolution significantly shifted the relative combined military and economic efficiency to the advantage of the western nations. Military capacity between the western industrialized nations and the rest of the world became extremely asymmetric. Furthermore, the industrial revolution greatly increased the logistical capacity of the industrialized nations and their military. Western great powers possessed far greater capability to project power overseas due to the industrial revolution. The industrialization and mechanization of warfare caused the mass factor to become larger. The outcome was an extremely high concentration of resources and capability in the hands of the western industrial nations.

Conquests of far-flung corners of the world became possible given the greater logistical capacity and the larger mass factor. The whole globe was subjected to political and military penetration by the western industrialized nations. ${ }^{252}$ Even the gunpowder empires of the major oriental Eurasian cultures found it hard to resist encroachments from the West after the industrial revolution. Of course the other major cultures responded and resisted, yet their responses and resistance were mostly unsuccessful, especially initially, given the sudden drastic changes in relative combined military and economic efficiency due to the industrial revolution. The only notable exception was Japan.

The fragmented geography of Japan and high contestability of the Tokugawa Shogunate meant that Japan, unlike the other major non-European Eurasian cultures, had sunk least into the slumber of gunpowder imperial complacency and conservatism. Cultures, customs, institutions and policies were less at odds with the requirements of a modern state, economy and society. This was especially so given that there were still many feudal lords in Japan that were highly independent of the Tokugawa Shogunate. These feudal lords were mainly concentrated in southwestern Japan. A spirit of competition still survived in the Japanese system. Therefore, once there was a political will to modernize, there were less frictions and obstacles to obstruct the effort and hence the

252 Refer to Parker (1995).

(cc) BY-NC-ND 
move for reforms was easier for Japan than for the other major oriental cultures. Furthermore, the relatively more fragmented Japanese political system during the Tokugawa Shogunate also meant that it was much easier for the reformed minded regional lords to challenge the power of the complacent and conservative Tokugawa Shogunate and take over the government and steer Japan on a course of reform. Consequently, Japan responded to the challenge of the Western great powers decisively and rationally by undertaking a drastic westernization program, while the responses of the other major gunpowder empires were much more lukewarm.

Another important reason for the early failure of the other major cultures in responding to challenges from the West during this period was the size of the mass factor. A large mass factor confers great advantage to the more efficient and stronger contestant, and the weaker rival thereby has a smaller chance of victory. A larger capability is thus transformed into a great advantage in conflicts, and any defeat could be decisive. Consequently, India was colonized and the Ottoman Empire, Persia and China lost much of their territory and sphere of influence. Even Japan, the only major culture that succeeded in meeting the Western challenge by full-heartedly and completely westernizing itself, suffered defeats and humiliations during her initial contacts with the Western powers.

The failure of the rest in resisting Western encroachments and colonization turned international politics into an internal struggle between Western nations. Yet, the intense political-military competition among the Western great powers culminated in two world wars which weakened the Western nations and helped to end the Western dominance over the rest. The global state system that the West created was transformed into a westernized global state system.

There were important military technological changes that led to the retreat of Western powers and the political independence of the rest, as well as a resurgence of the older major cultures. Two important macro historical forces were at work here. The first was the decreasing size of the mass factor. The consequence was a more symmetrical distribution of resources and capability. In the language of international relations scholars, it was a move towards the multi-polar world order. In the language of macro historians, it was the coming of a new medieval era. The above mega-trend allowed the next mega-trend time to work itself out. The next mega-trend was the diffusion of knowledge across civilizations and nations. ${ }^{253}$ This process led to a more symmetrical distribution of relative combined military and economic efficiency. This mega-trend further reinforced the movement toward a more symmetrical distribution of resources and capability and a multi-polar world order initiated by a small mass factor.

253 Refer to McNeill $(1963,1998)$. 
The rise of mass politics and its associated guerrilla warfare and the development of nuclear weapons caused the reduction in the size of the mass factor. These military technological changes also lead to a more symmetrical relative combined military and economic efficiency between the advanced nations and the developing world. The industrial revolution brought forth many new products, including the invention and use of mass media and mass printing. These inventions released the power of the general public. Mass involvement in politics and warfare made war total. The battleground between advanced powers and backward societies was to some extent leveled. With mass involvement and guerrilla warfare, international conflicts became prolonged and less decisive. Economies of scale in conflicts became smaller.

Given a smaller mass factor, the western great powers, despite their advanced technology, better organization and larger resource base, lost part of their strategic advantage. With the loss of parts of their military and political advantage, the western powers retreated, especially after World War II. The rise of communist China under the leadership of a totalitarian mass party and the independence of India and other Asian states through mass popular resistance movements testified to the coming of a new political-military macro-historical era. The invention of nuclear weapons further leveled the playing field between advanced and less developed nations. With nuclear weapons, it became almost impossible to attack and conquer another nuclear power, no matter how backward it is. Consequently, communist China, despite its international isolation, policy failures, and poverty, retained its independence and integrity throughout the Cold War. Mass politics won India its independence, something that India had not enjoyed for centuries-not since the Mughal Empire fell to the British colonial regime. Other smaller nations benefited from the smaller economies of scale in conflict as well. For instance, Vietnam defeated France and America to regain independence and unification. The military-political preconditions for the resurgence of the non-western world were laid down.

The above restructuring in international politics created a more even distribution of capability. The more even distribution of capability energized the independent non-western nations to greater developmental effort. Through trial and error and experimenting with different development strategies, the non-western states have slowly acquired a share of the world economy more proportionate to their national potential. After centuries of decline and stagnation, the Asian economies have boomed again in recent decades. First it was Japan who industrialized in late nineteenth century after Meiji Restoration and rebuilt herself after the destruction of World War II. Then the newly industrialized economies of South Korea, Taiwan, Hong Kong and Singapore emerged after World War II. Then it was the second wave of newly industrialized economies of Malaysia, Thailand and Vietnam, and the giant economies of China and India. By projection, within decades, Asia will regain its historical preeminence 
in the world economy. ${ }^{254}$ Other non-western nations forge ahead as well, most notably Brazil. Rising along with the rapid growth of the Chinese, Indian, Brazilian and other non-western economies is their overall national power, including military power. ${ }^{255}$

The resurgences of China and India are especially illuminating on how international political-military competition spurs economic development. The need to cope with the threat from the former Soviet Union and the United States, and to regain its traditional preeminence in the international arena, prompted Deng Xiaoping's reforms in China. Isolationist and socialist policies were abandoned in favor of market-oriented reforms and open door policies. The Chinese economy took off, and China's economic rise has increased its overall national power. This alarmed the surrounding nations, including the other Asian giant, India. India responded to the economic rise of China by starting its own economic reforms, ending her self-sufficiency policy and socialist measures in favor of greater integration with the world economy and market-friendly policies. All these were adopted with the goal of faster economic growth and greater national power. Other economies in the region have followed suit as well. In sum, these major non-western nations are competitively mobilizing economic resources for greater capability in the international arena, as happened repetitively in world history.

An important technological change that has and is still shaping the contemporary global state system is the computer technology. It decreases the economies of scale in information technology and production which leads to the downsizing of firms and the decline of American manufacturing. It also leads to the rise of smaller firms from Japan and the small, East Asian newly industrializing economies of Korea, Taiwan, Hong Kong and Singapore as well as other late comers in industrialization. Another result it brings is a decline of the mass factor. It helps in the miniaturization of weapons, especially weapons with mass destruction capability. The decreasing mass factor due to changes in current military technology together with the decreasing scale of production and information technology increases the difficult of state building and maintenance and state resource extraction and led to increasing number of non state force wielding organizations. This might explains the increasing cases of state failure in the contemporary world. Therefore, the big question confronting us is - will there be a new dark age in the future, as one that followed the collapse of the Roman Empire?256 And what would be the economic consequences of these technological changes? The analytical concepts exposed in this book will definitely be useful in the search for an answer.

254 Refer to Pomeranz (2000).

255 Refer to Samuels (1994), Cohen (2001), Feignebaum (2003) and Ganguly (2003).

256 Refer to Bonomo, Bergamo, Frelinger, Gordon IV and Jackson (2007). 